\title{
LUT
}

Lappeenranta

University of Technology

\section{Fostering inclusive innovation in developing economies: An integrative framework for MNEs}

Mortazavi Sina, Laine Igor, Teplov Roman, Väätänen Juha, Gupta Suraksha

This is a Author's accepted manuscript (AAM) version of a publication published by Springer, Cham

in Globalization and Development. Contributions to Management Science.

DOI: 10.1007/978-3-030-11766-5_4

Copyright of the original publication: (C) 2019 Springer Nature Switzerland AG

Please cite the publication as follows:

Mortazavi S., Laine I., Teplov R., Väätänen J., Gupta S. (2019). Fostering Inclusive Innovation in Developing Economies: An Integrative Framework for Multinational Enterprises. In: Faghin N. (eds) Globalization and Development. Contributions to Management Science. Springer, Cham. DOI: 10.1007/978-3-030-11766-5_4 


\title{
Fostering inclusive innovation in developing economies: An integrative framework for MNEs
}

\section{Authors:}

Sina Mortazavi ${ }^{1}$ (sina.mortazavi@1ut.fi)

Junior Researcher

Igor Laine ${ }^{1}$ (igor.laine@lut.fi)

Post-Doctoral Researcher

Roman Teplov ${ }^{1}$ (Roman.Teplov@1ut.fi)

Junior Researcher

Juha Väätänen ${ }^{1}$ (Juha.Vaatanen@ @lut.fi)

Professor of International Business and Emerging Markets

Suraksha Gupta² (suraksha.gupta@ncl.ac.uk)

Professor of Marketing

1 Lappeenranta University of Technology, Lappeenranta, Finland; 2 University of Newcastle, Newcastle, UK

\begin{abstract}
A relatively new term emerging in the last decade, inclusive innovation commonly refers to any innovation for poor and otherwise excluded members of society. Developing economies are particularly promising targets for this kind of innovation due to their institutional voids and vast numbers of people living below the poverty line. This paper introduces an integrative framework highlighting a range of factors relevant for multinationals seeking to foster inclusive innovation in developing economies. Because innovation processes in developing economies inherently face constraints, our suggested approach mitigates and transforms these challenges into advantages that assist both multinationals and the local societies. We argue that this approach fits the context of developing countries better than traditional methods applied in developed countries; as such multinationals operating in these markets should embrace it within their strategies. By building on
\end{abstract}


contemporary research into the strategy, entrepreneurship and supply chain literature while extending beyond the conventional understanding of innovation processes, our study develops an integrative framework of inclusive innovation for multinationals operating in developing economies. On a practical level, our study can help managers understand inclusive innovation and their respective operational strategies, thus enabling effective innovative processes in developing countries.

Keywords: Inclusive innovation, developing economies, multinational enterprise, international business, operating constraints.

\section{INTRODUCTION}

Innovation must be attained even when facing the major operating constraints characterizing developing countries. With recent decades featuring ongoing globalization and the rise of developing economies, researchers have posed new innovation practices and vocabulary, including new approaches and innovation types. Several new terms have emerged, such as frugal, reverse, inclusive and Gandhian innovation, to name a few-all of these terms refer to innovations originating in developing countries (Brem and Wolfram 2014; Prahalad and Mashelkar 2010; Rosca et al. 2016). The current study focuses on one of these specific types of innovation, inclusive innovation, a term that can be defined broadly as any innovation aiming to enhance the wellbeing of economically or socially excluded people (Foster and Heeks 2013; Gold et al. 2013). Notably, oftentimes researchers confined inclusive innovation to the context of the so-called bottom (base) of the pyramid (BOP). The BOP consists of an estimated 4 billion poor people around the world living on less than two US dollars per day and lacking access to basic goods and services (Prahalad 
2012; Sinha et al. 2017). We take a broader view of its potential application, arguing that the inclusive innovation approach can be applied effectively to the larger context of developing economies as a way of tapping into previously unseen and undervalued opportunities. Despite relatively similar features in terms of operating and institutional constraints, developing markets have achieved varying degrees of progress (Hoskisson et al. 2013). We keep in mind the diverse developmental paths of these countries while considering the possibilities of global economic forces in order to tap into previously excluded layers of people. For example, in more successful developing countries like China, recent decades have brought an enormous number of hitherto excluded people (mostly from rural areas) into the formal economy, thus improving their wellbeing. By comparison, in places like Sub-Saharan Africa and India, the number of poor and forgotten people continues to increase in spite of international aid and other measures (Chataway et al. 2014). Motivated by these drastic differences in the progress of developing economies and the role played by multinationals, we aim to fill an important gap in the international business (IB) literature by addressing the following research question: How can multinationals effectively foster inclusive innovations when facing the constraints of developing economies?

Our conceptual paper seeks to contribute to IB research in a number of ways. First, it attempts to bridge a research gap in the IB literature by addressing inclusive innovation within the constraints of developing economies from a multinational enterprise (MNE) perspective. Secondly, this paper aims to enhance our conceptual understanding by taking into account the specific contexts of developing economies, particularly in terms of innovation-related constraints; it thus assists in developing a more nuanced approach to innovation specifically focused on the needs of marginalized and excluded people in these markets. Our suggested integrative framework for fostering inclusive innovation in developing economies using an MNE perspective assists in 
explaining the MNEs' ability to foster inclusive innovation in developing economies. Ultimately, the integrative framework we propose in this article may contribute to the broader discussion on the strategy of multinational enterprises under constraints of developing economies. Finally, our study may assist practitioners by providing insights into effective implementation of inclusive innovation, uncovering the previously untapped potential of developing markets.

The rest of this paper unfolds in the following way. In the next section, we provide a literature review on inclusive innovation and the various challenges that MNEs face in emerging markets. Based on the literature review, we develop an integrative framework of inclusive innovation by conceptualizing how multinationals can foster inclusive innovation in developing economies. We conclude by discussing how the suggested framework and separate propositions can serve a subject for further empirical examination.

\section{THE STATE OF THE LITERATURE ON INCLUSIVE INNOVATION}

Although the concept of inclusive innovation takes its roots from the bottom of the pyramid literature (Prahalad and Hart 2002), the term itself formally was defined only recently (Foster and Heeks 2013). Inclusive innovation refers to innovative models and tools focusing on the marginalized members of society while involving new technology (Heeks et al. 2014, p. 4). Though inclusive innovation has received extensive attention from the research community, the concept remains bound to the context of the bottom of the pyramid literature (Hart 2005; Hart and Christensen 2002; Prahalad and Hart 2002; Prahalad and Mashelkar 2010). Amidst growing attention, this phenomenon has become the focus of a number of special issues within well-known journals, including the Journal of Management Studies (2012) and the Journal of Innovation and Development (2014); meanwhile, it has emerged as an important topic in the recently-established Journal of Frugal Innovation (George et al. 2012; Heeks et al. 2014; Vadakkepat et al. 2015). The 
United Nations and governing bodies in developing nations have highlighted inclusive innovation as a vital measure for fighting poverty in developing countries (Planning Commission 2013; Prahalad and Mashelkar 2010; United Nations 2015).

It has become commonplace for multinational enterprises (MNEs) to invest large amounts of money in carrying out innovation strategies in developing markets; for example, the large market of India is becoming increasingly appealing for international firms (Immelt et al. 2009; Prahalad and Krishnan 2008; Rajan 2007). Many MNEs now seek to create affordable offerings for these lower-income markets, overcoming production and strategic barriers along the way (Prahalad and Mashelkar 2010). Illustrative of this case, Tata motors, a successful automotive firm, extensively employed frugal production while simultaneously enhancing livelihoods in India. Despite many challenges concerning production and environmental issues (Pervez et al. 2013; Shafiulla 2014), the Tata Nano team created the cheapest car in the world by using an innovative approach to meet Indian safety, design and environmental standards (Prahalad and Krishnan 2008). Similarly, Unilever decided to sell its products to BOP markets in smaller quantities, making it more affordable for the target market. According to Rajan (2007), Unilever used a BOP-friendly pricing strategy and sold goods in packets (e.g., shampoo and instant coffee) at affordable prices. General Electric (GE) also is striving to achieve frugal and innovative changes that can result in affordable products for developing markets while overcoming competition barriers (Immelt et al. 2009). GE has attained past growth in the Indian market with the help of local governments. Such initiatives have led to the inclusive growth and employment of 12,000 people in India (Dossani and Kenney 2007). In 2009, GE announced $\$ 3$ billion worth of investments over the following six years to finance about 100 health-care innovations for the BOP in the rural areas of China and India (Immelt et al. 2009). These three different cases demonstrate that MNEs are tailoring their strategies to 
provide the innovation demanded in poor markets. However, the above cases represent a minority of MNEs; the majority faces challenges when entering these markets or simply tries to avoid them (Karnani 2007). Prahalad (2004) argues that MNEs lack the motivation and incentive to invest in developing countries with a substantial number of people belonging to the BOP. At the same time, he asserts that poor markets are no different from markets consisting of people with buying power and access to distribution channels who demand quality products and services at affordable price (Prahalad 2004).

Only with appropriate strategies and production can MNEs gain profitability from low-income markets in developing countries (Brenes et al. 2014). They must balance a strategy that will result in affordably-priced goods while encouraging inclusive growth at the BOP (Gupta 2017; Jones 2010). For example, some MNEs in the pharmaceutical sector tend to launch products and services at a very low price, thus intensifying market competition (Gupta 2017; Hill et al. 2014; Prahalad and Mashelkar 2010). Their strategies are found to be deficient because they fail to adapt their offerings to the specific needs and settings of developing countries (Dahan et al. 2010; Prahalad 2004; Prahalad and Mashelkar 2010). In other words, MNEs from advanced economies oftentimes lack the knowledge needed to operate in developing countries, while the approach suggested in this article enables learning and brings possibility to gain leverage from resources currently underutilized and hidden.

With growing attention from the research community and various think tanks, guidelines on how MNEs can effectively foster inclusive innovation in developing economies would serve as a timely contribution. While scholars have outlined some of the resource constraints in emerging markets and sustainable business models for frugal innovation, the literature has fallen short of suggesting an effective mechanism for fostering inclusive innovation; such a mechanism could allow MNEs 
to gain better positioning and contribute to the wellbeing of excluded people in these markets (Amit and Zott 2001; Bock et al. 2012; Hart 2005; Prahalad 2004; Rosca et al. 2016; Zeschky et al. 2014).

The innovation research has yet to propose a theoretical understanding of the strategies MNEs require to overcome product constraints and achieve inclusive innovation (Belderbos and Zou 2007; Tihanyi et al. 2005). Indeed, several studies have pointed out the need for additional research into MNEs' production challenges as well as the products or services they could offer to promote inclusive growth at the BOP while taking into account market competition(Banerjee and Duflo 2011; George et al. 2012; Karnani 2007). The innovation literature has provided promising insights into frugal innovation, reverse innovation and Gandhian innovation (Brem and Wolfram 2014; Prahalad and Mashelkar 2010; Rosca et al. 2016). The current body of work has focused on modes of innovation (Heeks et al. 2014), the impact of leadership on inclusive innovation (Javed et al. 2017), inclusive capitalism and the benefits of inclusive growth for MNEs (Ansari et al. 2012), capital barriers for inclusive innovation (George et al. 2012) and systems for inclusive innovation (Foster and Heeks 2013). At the same time, researchers have overlooked how MNEs can attain inclusive innovation through operational strategies and adaptation to the innovation constraints in developing markets.

From a managerial perspective, MNEs already have been active for decades in many developing countries where they sell products and services (Nijhof et al. 2002). However, when MNEs aim to incorporate inclusive innovation into their strategic repertoire for developing markets, managers must deal with various barriers on the way to profitability (Prahalad 2004). Additionally, MNEs must be conscious of the main objective of inclusive innovation - addressing poverty issues and creating livelihood opportunities for local people. This objective implies a primary goal not only 
of gaining profitability but also of promoting livelihood opportunities for otherwise socially and economically excluded people (George et al. 2012; Prahalad 2004). Selling products and services lower-income developing markets also has to be accomplished through frugal approaches that allow the maximization of value amidst resource scarcity (Hossain et al. 2016). As a result, the firm has to move beyond its comfort zone and develop products and services (or a combination of both) that are inexpensive, sustainable and user-friendly.

As outlined by Prahalad (2004), MNEs are able to attain both inclusive innovation and profitability by networking with partners, such as government bodies. MNEs' networking strategies in emerging markets like India have brought about promising growth with government assistance making the BOP more attractive through subsidies and flexible taxation for investors (Caldwell et al. 2017; Patil and Laishram 2016). Despite partnerships between MNEs and local entrepreneurs and governments in developing nations, the topic has remained uncharted territory for scholars. According to Hall et al. (2012), governments in emerging nations view entrepreneurship as a potential tool for poverty reduction.

Nevertheless, practical approaches what MNEs should do to successfully utilize hidden innovative potential in developing countries by pursuing inclusive innovation remain an overlooked but promising are to study. To address the above-outlined complexities of the focal concept in the context of developing economies, by drawing from the current literature in strategy, entrepreneurship and supply chain management the next section develops an integrative framework of inclusive innovation for MNEs. 


\section{TOWARDS AN INTEGRATIVE FRAMEWORK FOR MNES}

As stated in the previews sections, MNEs have emerged as increasingly important actors in today's globalized world, yet, in developing countries, they face a distinct set of problems. Our framework proposes solutions to some of the challenges MNEs face when it comes to developing innovations in these countries. Inclusive innovation can be a useful tool for MNEs in the BOP market to gain shared benefits. However, as the notion of inclusive innovation is still new for researchers, there remains a lack of connection between inclusive innovation as a concept and its practical implementation at the BOP (Halme et al. 2012). Weick (1989) argues that new concepts can benefit from the theorizing and/or conceptualizing process, including the borrowing of notions from different research disciplines that could suit the context in question; such cross-disciplinary pursuits could lead to modifying and improving the concept itself. Given that inclusive innovation represents a new phenomenon for IB research, we seek to use existing constructs from other streams in the management literature in order to conceptualize it.

In a special issue of the Journal of Management Studies, George et al. (2012) noted that inclusive innovation is a very new topic in management research, one that could benefit from management theories in marketing, entrepreneurship and strategy. Indeed, several articles from the IB literature about social development in emerging markets have used constructs from these streams: marketing (Gupta 2017; Reficco and Márquez 2012; Sinha et al. 2017), strategy (Gugler and Shi 2009; Kolk and van Tulder 2010; Vachani et al. 2009), entrepreneurship (Caldwell et al. 2017; Dacin et al. 2010; Kotha and George 2012; Weber et al. 2017), international business (Andersson et al. 2001;

Doh et al. 2017; Pitelis and Teece 2018; Yamin and Andersson 2011), and supply chain management (Gold et al. 2013). However, scholars have not combined these streams to address MNEs' challenges in achieving inclusive innovation in developing countries. As a result, we seek 
to conceptualize inclusive innovation based on theoretical underpinnings derived from entrepreneurship, marketing, international business, and strategic and supply chain management streams of literature. In particular, in order to develop our integrative framework for MNEs on top of the current contributions in innovation literature discussed in previous section, we draw on the specific concepts from the above-outlined disciplines including social entrepreneurship (Dacin et al. 2010; Marshall 2011), sustainability and corporate social responsibility (Kolk 2016; Quarshie et al. 2016; Vachani et al. 2009), product adaptation (Johnson and Arunthanes 1995; Vinson et al. 1977) ,bricolage (Baker et al. 2003; Baker and Nelson 2005; Desa 2012), embeddedness and networking (Andersson et al. 2001; Dhanaraj 2007; Garcia-Pont et al. 2009; Hansen 1995; Yamin and Andersson 2011).

\section{Macro-environment: Innovation constraints in developing markets}

Developing economies are prone to various constraints hindering potential innovative initiatives and restricting economic and technological growth in these markets. Multinational enterprises tend to be demotivated from carrying out innovative activities in these risky, uncertain and underdeveloped markets. This fact particularly applies given that many industrialized nations are facing financially constrained agendas, and R\&D budgets are steering clear of large investments with uncertain outcomes. The traditional approach to innovation in developed economies is "built on assumptions of affluence and abundance" (Prahalad and Mashelkar 2010, p. 133). As such, the resource-constrained environment of developing economies presents a rather challenging setting (Sharma and Iyer 2012). The thin margins on potential offerings only become profitable at enormous volumes, requiring market access that extends far beyond the existing customer base. Because poor markets demand low-priced products with acceptable quality, conventional approaches to selling goods often fail due to uncertainties and constraints (Prahalad and Mashelkar 
2010). As a result, operating in poor markets demands innovations that overcome constraints while offering products for reasonable prices. This mechanism often is referred to as Jugaad innovation, where the innovator aims to guarantee low prices while keeping production constraints to a minimum (Singh et al. 2012). Various studies confirm that a firm can successfully adapt a product and overcome constraints by accounting for important factors like host countries' cultures and regulations as well as existing parallel product offerings (Cavusgil and Zou 1994; Johnson and Arunthanes 1995; Vinson et al. 1977). However, many scholars point out that poor markets in developing countries require more customized adaptation strategies because these markets differ drastically in terms of distribution and production constraints (Cavusgil and Zou 1994; Zhu et al. 2017).

According to London and Hart (2004), MNEs often make the mistake of transferring the same product concept sold in their home country to developing countries, causing losses. Even though some large MNEs like Unilever have included product adaptation strategies for lower-income developing markets in their business models (aiming to tailor products to the market), many others struggle with production barriers (London and Hart 2004). When trying to achieve inclusive innovation for the BOP, profitability and sales are important incentives for MNEs, and product adaptation strategies can play a vital role in promoting success in these markets (Prahalad 2004). Nevertheless, MNEs view availability and distribution as challenges in developing markets due to a lack of sufficient infrastructure and relevant institutions (Bland and Hamann 2015; Chaudhuri et al. 2009; Doh et al. 2017; Palepu and Khanna 2010). As a result, we reach the following propositions:

Proposition 1: Production constraints in developing economies discourage MNEs from developing inclusive innovations in these markets. 
Proposition 1b: Distribution constraints in developing countries negatively affect the ability of MNEs to generate inclusive innovation in these markets.

\section{$\underline{\text { Micro-environment: Multinational enterprises }}$}

With the above operating constraints in mind, multinational companies tend to seek ways of mitigating them, even turning them into opportunities. The approach proposed in this paper suggests that inclusive innovation in developing economies can be attained by applying the principles of inclusivity to multinationals' resource management, supply chain management and organizational embeddedness. Below, we offer a detailed discussion of the three pillars of inclusive innovation: inclusive resource management, inclusive supply chain management and inclusive embeddedness.

\section{Inclusive Resource Management}

The resource-based view argues that firms can attain comparative advantage and achieve their goals through effective resource management (Barney 1991). When referring to a firm's resources, we often discuss knowledge, physical capital, partnership (ties between actors), networking capabilities, distribution channels, brand and similar company properties (Wernerfelt 1984). Resource management holds importance in achieving inclusive innovation (George et al. 2012). Inclusive resource management can assist companies in overcoming production constraints utilizing externally available resources; however, the greatest contribution of inclusive resource management is its ability to reduce costs and generate low-cost innovations in developing countries while overcoming resource constraints. For instance, effective resource management by means of bricolage could help MNE managers to overcome production barriers (Baker and Nelson 2005). Bricolage is a concept closely linked to firm innovation; in essence, firms can find ways to combine existing resources more efficiently using creative reconstruction methods to produce goods at 
lower prices (Baker and Nelson 2005; Kincheloe 2005; Sunduramurthy et al. 2016). Thus, we propose the following:

Proposition 2: Inclusive resource management for MNEs operating in developing countries can reduce the negative impacts of production constraints on inclusive innovation.

\section{Inclusive Supply Chain Management}

Attaining inclusive innovation in developing economies is difficult because MNEs must cut prices and find solutions in order to deliver products to less dense geographic areas (Prahalad and Mashelkar 2010). To foster innovation in conventional production, firms can integrate the supply chain channel, but in resource-constrained markets, they have no choice but to use the existing supply chain and distribution channels (Sharma and Iyer 2012). However, if the companies manage to make the supply chain channels more inclusive (e.g., connecting urban and rural areas), they can gain more ground in the market and streamline their production more effectively (Palepu and Khanna 2010). Some MNEs like Nestlé have developed their supply chain and logistics specifically to have a more inclusive scope for poor and rural areas in developing countries; however, many other MNEs continue to face challenges (Porter and Kramer 2011). Traditional urban markets hold more resources for MNEs, and it is easier to upgrade or integrate the supply chain channels within these markets. However, poor rural areas have the greatest humanitarian potential for innovation (Perez-Aleman and Sandilands 2008). Sourcing local people to attain efficiency in the supply chain is a method that allows companies to overcome institutional void constraints (Palepu and Khanna 2010; Reficco and Márquez 2012). Based on the above discussion, we arrive at the following proposition: 
Proposition 3: For MNEs operating in developing countries, inclusive supply chain management reduces the negative impact of distribution constraints on inclusive innovation.

\section{Inclusive Embeddedness}

In our integrative framework for MNEs, the final pillar of inclusive innovation is inclusive embeddedness. Firm performance relies heavily on the level of embeddedness a firm establishes with various market actors. Traditional actors (governmental or non-governmental organizations) provide a firm access to resources, such as knowledge, capital, human resources and other valuable assets (Burt 1995; Möller and Halinen 1999); however, companies need to understand the importance of non-traditional actors (e.g., not-for-profit organizations, community groups) in poor markets (Hart and London 2005). According to Levin and Cross (2004), strong ties between market actors can generate useful knowledge both for production and distribution activities. While the network approach remains popular in international business and entrepreneurship research (Hansen 1995; Johanson and Mattsson 1988), it also can be especially helpful in developing economies by bringing growth and stability to these markets (Dhanaraj 2007; Khayesi and George 2011). In developing countries lacking existing innovation structures, multinationals can play an orchestrating role (Pitelis and Teece 2018) in establishing new innovation networks while coping with infrastructural challenges. Being embedded in various local networks and fostering social entrepreneurship can help companies address social needs through collaboration and partnership, leading to value creation for the poor (Caldwell et al. 2017; Dacin et al. 2010; Weber et al. 2017). Social entrepreneurship - defined as using entrepreneurial knowledge to create value and fulfill social needs rather than focusing only on profit - creates a positive image for the involved multinational and enhances its societal embeddedness (Gupta et al. 2008; Hibbert et al. 2005). The 
value gained from collaboration and networking is defined as the sum of benefits obtained from resource exchanges between the public and private sectors (Caldwell et al. 2017). A common method for networking and collaboration between MNEs, non-profit organizations and public institutions (governmental bodies of the hosting country) is the cross-border joint venture. These ventures involve networking between international firms and local organizations in the host country in order to hasten learning, thus easing the effect of resource sharing and reducing risks (Park and Ungson 1997). However, the inclusive innovation literature has overlooked the effect of networking between MNEs, traditional actors and non-traditional actors. Reficco and Márquez (2012) have argued that the institutional void in poor markets can be filled through networking with non-traditional actors, but this idea has not yet been studied in the context of innovation. Some studies demonstrate that, when facing resource limitations, companies can benefit from inclusive embeddedness in networks of traditional and non-traditional actors, thus overcoming the cost constraints of developing nations (Khayesi and George 2011; Reficco and Márquez 2012). As a result, we make the following propositions:

Proposition 4a: Inclusive embeddedness by MNEs operating in developing countries reduces the negative impact of production constraints on inclusive innovation.

Proposition 4b: Inclusive embeddedness by MNEs operating in developing countries reduces the negative impact of distribution constraints on inclusive innovation.

\section{The benefits of inclusive innovation to developing economies}

We now have discussed the macro-level environmental characteristics of developing economies that form barriers to inclusive innovation as well as the micro-level activities that can help MNEs overcome such constraints. Here, we need to account for the inevitable feedback loop as the very 
nature of inclusive innovation assumes the involvement of a larger number of people in economic activity (Foster and Heeks 2013; Heeks et al. 2014).

As far as inequality were found to be holding back social and economic development (Stiglitz 2012), inclusive innovation specifically aimed to reduce inequality thus boosts social and economic wellbeing particularly in developing countries where the problem is especially evident. There exists a win-win situation in creating innovations addressing the BOP market profit-seeking international business. Rising consumption will create more demand for local products, sparking a cycle of increasing domestic growth while lifting these developing countries and their consumers up to greater economic opportunity and better lives (Czinkota and Ronkainen 2010). From the business perspective, this growth also means gradual environmental improvements and the elimination of negative macro-level barriers. As such, we propose the following:

Proposition 5: Inclusive innovation in developing economies positively affects the macroenvironment of these markets.

The figure below (Figure 1) summarizes the outlined propositions into an integrative framework of inclusive innovation for MNEs operating in developing countries. 
Figure 1. An integrative framework of inclusive innovation for MNEs

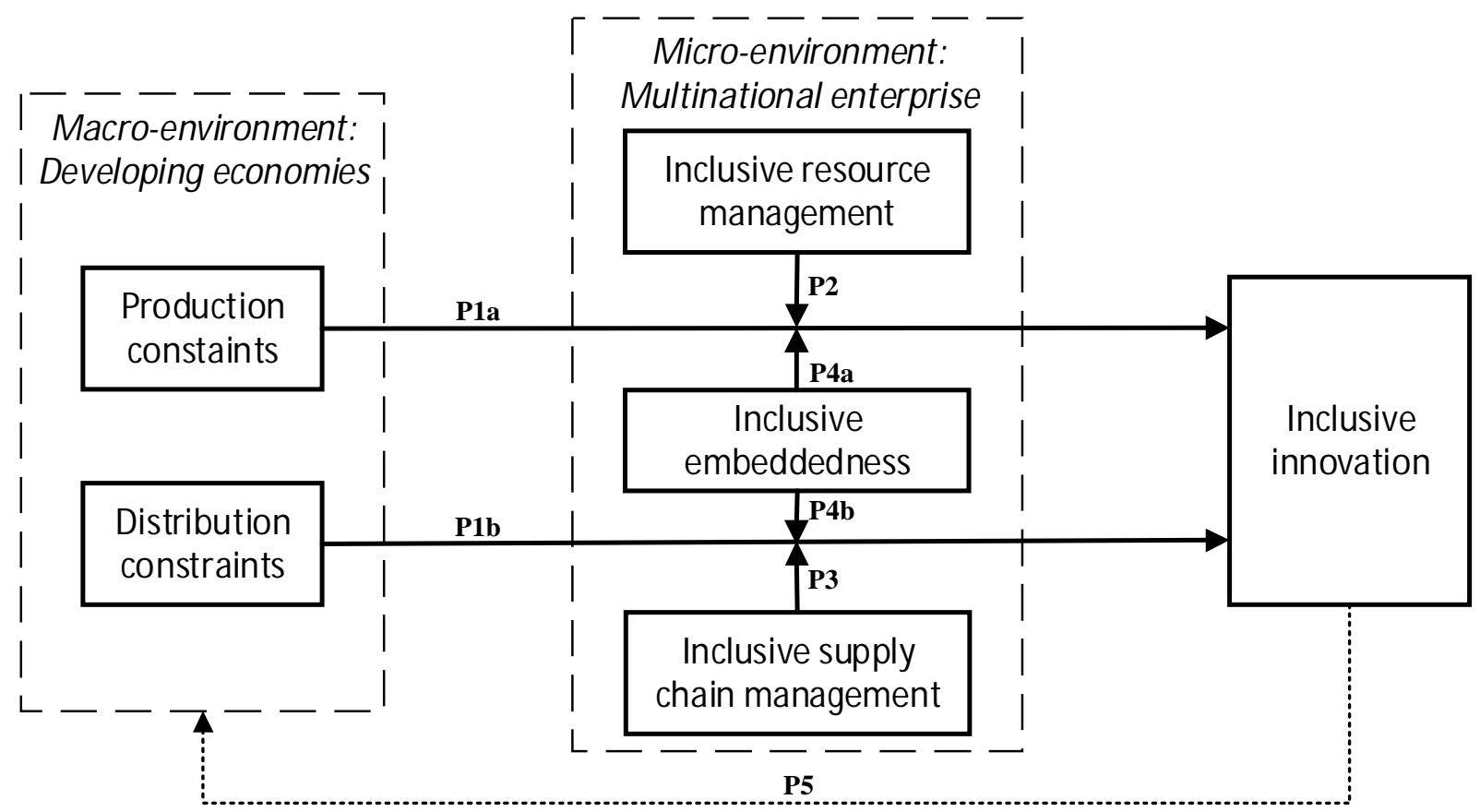

The next section discusses the framework in light of the existing literature and presents our concluding remarks.

\section{DISCUSSION AND CONCLUSIONS}

\section{Theoretical implications}

This study contributes and extends the IB literature in a number of ways. First, the suggested integrative framework conceptualizes how a multinational enterprise can effectively foster inclusive innovation in the constrained environments of developing economies by means of inclusivity in resource management, supply chain and organizational embeddedness. The benefits of inclusive innovation have been recognized by the United Nations as well as the governing 
bodies of developing countries and many MNEs (George et al. 2012; Prahalad 2004; Prahalad and Hart 2002; Prahalad and Mashelkar 2010; United Nations 2015, 2016), and our study enhances the conceptual clarity of the contested notion of inclusive innovation. Our research clarifies the complexities of this concept and opens a path for future scholars to test and develop the propositions further. Second, this research responds to George et al.'s (2012) call for theoretical advancement on inclusive innovation in IB research because the area remains in its nascent phase. The literature on developing economies provides valuable insights into how and why MNEs have expanded into these markets by leveraging competitive advantage. Many MNEs are basing their efforts in emerging markets on trickle-down approach to innovation when products initially developed in advanced markets are supplied to developing world when their life-cycle allows for affordable pricing (Vernon 1966). However, our research suggests that it is better for managers to shift their strategic focus to challenging but promising developing economies as a source and target of innovation. This conceptual paper suggests an alternative path by establishing competitive advantage in developing countries by means of inclusive innovation to overcome the constraints of these markets. Prahalad (2004) unveiled the fact that lower-income markets such as the BOP hold hidden opportunities for MNEs. By taking advantage of these opportunities, an MNE can establish itself as a socially-embedded actor and enhance its competitive positioning and profitability while improving the livelihoods of local people. Ultimately, our research suggests that MNEs can gain operations in poor regions of developing countries through inclusive innovation by considering the operational mechanisms for these markets, leading to enhanced livelihood opportunities in developing economies. 


\section{$\underline{\text { Managerial implications }}$}

Nothing is easy, but everything is possible: this common mantra often is uttered by managers working in developing countries. The same applies to innovation management in these constrained operative environments where innovation requires an alternative approach like the one suggested by this study. After relevant empirical validation, this paper can serve as a guideline for MNE board members and managers aiming to enter BOP markets. The IB literature has documented how many well-known firms (Unilever, Tata Motors and GE) have gained profitability by entering low-income markets in developing countries. However, many others lack the motivation to take on the many challenges of poor markets. Our conceptual research provides suggestions for MNEs seeking a competitive edge in developing economies by means of inclusive innovation. We outline how MNEs can use operational strategies tailored to these markets in order to overcome their inherent constraints to innovation. Managers are suggested to take into account both production and distribution issues and to develop an innovation strategy in accordance to the principles of inclusivity described in our study. Finally, it must be noted that an inclusive approach to innovation in the strategic repertoire of MNEs will benefit both firms and the local communities of developing countries.

\section{Further research and conclusion}

This paper has attempted to conceptualize how MNEs can attain inclusive innovation in developing economies by applying the principles of inclusivity to their resource management, supply chain and organizational embeddedness. Inclusive innovation is a very new notion requiring additional research. As the aim of this research was to develop an integrative framework of inclusive innovation for MNEs, future studies should test these propositions with primary data. Moreover, scholars are welcome to challenge the suggested conceptualization and discuss 
additional elements from different streams of management or other related areas of research that could strengthen the original framework. Finally, future studies could explore how MNEs' brand and impression management practices affect inclusive innovation in developing countries.

To conclude, this study's conceptualization offers insights into how MNEs can foster inclusive innovation in developing countries, suggesting an alternative approach to overcome the operating constraints of these markets. The study relied on contributions from different streams of literature - such as strategy, entrepreneurship and supply chain - in order to conceptualize inclusive innovation as a novel and practically relevant solution for MNEs operating in developing countries. The lessons emerging from this research can help scholars to broaden their knowledge of inclusive innovation while the presented propositions can be tested using deductive approaches to provide empirical validation. 


\section{REFERENCES}

Amit, R., \& Zott, C. (2001). Value creation in e-business. Strategic Management Journal, 22(67), 493-520.

Andersson, U., Forsgren, M., \& Holm, U. (2001). Subsidiary embeddedness and competence development in MNCs - A multi-level analysis. Organization Studies, 22(6), 1013-1034.

Ansari, S., Munir, K., \& Gregg, T. (2012). Impact at the "Bottom of the Pyramid": The Role of Social Capital in Capability Development and Community Empowerment. Journal of Management Studies, 49(4), 813-842.

Baker, T., Miner, A. S., \& Eesley, D. T. (2003). Improvising firms: Bricolage, account giving and improvisational competencies in the founding process. In Research Policy (Vol. 32, pp. 255276).

Baker, T., \& Nelson, R. E. (2005). Creating Something from Nothing: Resource Construction through Entrepreneurial Bricolage. Administrative Science Quarterly, 50(3), 329-366.

Banerjee, A. V., \& Duflo, E. (2011). Poor economics: A radical rethinking of the wat to fight global poverty. New York, NY: PublicAffairs.

Barney, J. B. (1991). Firm Resources and Sustained Competitive Advantage. Journal of Management, 17(1), 99-120.

Belderbos, R., \& Zou, J. (2007). On the growth of foreign affiliates: Multinational plant networks, joint ventures, and flexibility. Journal of International Business Studies, 38(7), 1095-1112.

Bland, C., \& Hamann, R. (2015). Obstacles to firms adoption of socially embedded approaches to BoP markets. In The Business of Social and Environmental Innovation: New Frontiers in Africa (pp. 105-127).

Bock, A. J., Opsahl, T., George, G., \& Gann, D. M. (2012). The Effects of Culture and Structure on Strategic Flexibility during Business Model Innovation. Journal of Management Studies, 49(2), 279-305.

Brem, A., \& Wolfram, P. (2014). Research and development from the bottom up - introduction of terminologies for new product development in emerging markets. Journal of Innovation and Entrepreneurship, 3(9), 1-22.

Brenes, E. R., Montoya, D., \& Ciravegna, L. (2014). Differentiation strategies in emerging markets: The case of Latin American agribusinesses. Journal of Business Research, 67(5), 847-855.

Burt, R. S. (1995). Structural holes: The social structure of competition. Harvard University Press. Cambridge, MA.: Harvard University Press.

Caldwell, N. D., Roehrich, J. K., \& George, G. (2017). Social Value Creation and Relational Coordination in Public-Private Collaborations. Journal of Management Studies, 54(6), 906928.

Cavusgil, S. T., \& Zou, S. (1994). Marketing Strategy-Performance Relationship: An Investigation 
of the Empirical Link in Export Market Ventures. Journal of Marketing, 58(1), 1.

Chataway, J., Hanlin, R., \& Kaplinsky, R. (2014). Inclusive innovation: an architecture for policy development. Innovation and Development, 4(1), 33-54.

Chaudhuri, A., Giffi, C., Kandaswami, K., \& Singh, S. K. (2009). Necessity Breeds Opportunity: Constraints, Innovation and Competitive Advantage. Deloitte Review, (4), 4-17.

Czinkota, M. R., \& Ronkainen, I. A. (2010). Global Business. Global Business: Positioning Ventures Ahead. Routledge.

Dacin, P. a, Dacin, M. T., \& Matear, M. (2010). Social entrepreneurship: Why we don't need a new theory and how we move forward from here. Academy of Management Perspectives, 24(3), 37-58.

Dahan, N. M., Doh, J. P., Oetzel, J., \& Yaziji, M. (2010). Corporate-NGO collaboration: Cocreating new business models for developing markets. Long Range Planning, 43(2-3), 326342 .

Desa, G. (2012). Resource Mobilization in International Social Entrepreneurship: Bricolage as a Mechanism of Institutional Transformation. Entrepreneurship: Theory and Practice, 36(4), $727-751$.

Dhanaraj, C. (2007). Managing the Embedded Multinational: A Business Network View. Journal of International Business Studies, 38(7), 1231-1233.

Doh, J., Rodrigues, S., Saka-Helmhout, A., \& Makhija, M. (2017). International business responses to institutional voids. Journal of International Business Studies.

Dossani, R., \& Kenney, M. (2007). The Next Wave of Globalization: Relocating Service Provision to India. World Development, 35(5), 772-791.

Foster, C., \& Heeks, R. (2013). Conceptualising inclusive innovation: Modifying systems of innovation frameworks to understand diffusion of new technology to low-income consumers. European Journal of Development Research, 25(3), 333-355.

Garcia-Pont, C., Canales, J. I., \& Noboa, F. (2009). Subsidiary strategy: The embeddedness component. Journal of Management Studies, 46(2), 182-214.

George, G., McGahan, A. M., \& Prabhu, J. (2012). Innovation for Inclusive Growth: Towards a Theoretical Framework and a Research Agenda. Journal of Management Studies, 49(4), 661683.

Gold, S., Hahn, R., \& Seuring, S. (2013). Sustainable supply chain management in "Base of the Pyramid" food projects-A path to triple bottom line approaches for multinationals? International Business Review, 22(5), 784-799.

Gugler, P., \& Shi, J. Y. J. (2009). Corporate social responsibility for developing country multinational corporations: Lost war in pertaining global competitiveness? In Journal of Business Ethics (Vol. 87, pp. 3-24).

Gupta, S. (2017). Returns on social development initiatives of MNEs: issues and perspectives. Qualitative Market Research: An International Journal, 20(2), 126-146. 
Gupta, S., Grant, S., \& Melewar, T. C. (2008). The expanding role of intangible assets of the brand. Management Decision, 46(6), 948-960.

Hall, J., Matos, S., Sheehan, L., \& Silvestre, B. (2012). Entrepreneurship and Innovation at the Base of the Pyramid: A Recipe for Inclusive Growth or Social Exclusion? Journal of Management Studies, 49(4), 785-812.

Halme, M., Lindeman, S., \& Linna, P. (2012). Innovation for Inclusive Business: Intrapreneurial Bricolage in Multinational Corporations. Journal of Management Studies, 49(4), 743-784.

Hansen, E. L. (1995). Entrepreneurial Networks and New Organization Growth. Entrepreneurship: Theory \& Practice, 19(4), 7-19.

Hart, S. L. (2005). Capitalism at the Crossroads. The Unlimited Business Opportunities in Solving the World's Most Difficult Problems. London, UK: Pearson Education.

Hart, S. L., \& Christensen, C. M. (2002). The Great Leap: Driving Innovation From the Base of the Pyramid. MIT Sloan Management Review, 44(1), 51-56.

Hart, S. L., \& London, T. (2005). Developing Native Capability: What multinational corporations can learn from the base of the pyramid. Stanford Social Innovation Review, 27-33.

Heeks, R., Foster, C., \& Nugroho, Y. (2014). New models of inclusive innovation for development. Innovation and Development, 4(2), 175-185.

Hibbert, S. a., Hogg, G., \& Quinn, T. (2005). Social entrepreneurship: understanding consumer motives for buying The Big Issue. Journal of Consumer Behaviour, 4(3), 159-172.

Hill, A., Khoo, S., Fortunak, J., Simmons, B., \& Ford, N. (2014). Minimum costs for producing hepatitis c direct-acting antivirals for use in large-scale treatment access programs in developing countries. Clinical Infectious Diseases, 58(7), 928-936.

Hoskisson, R. E., Wright, M., Filatotchev, I., \& Peng, M. W. (2013). Emerging Multinationals from Mid-Range Economies: The Influence of Institutions and Factor Markets. Journal of Management Studies, 50(7), 1295-1321.

Hossain, M., Simula, H., \& Halme, M. (2016). Can frugal go global? Diffusion patterns of frugal innovations. Technology in Society, 46, 132-139.

Immelt, J. R., Govindarajan, V., \& Trimble, C. (2009). How GE is disrupting itself. Harvard Business Review, 87(10).

Javed, B., Naqvi, S. M. M. R., Khan, A. K., Arjoon, S., \& Tayyeb, H. H. (2017). Impact of inclusive leadership on innovative work behavior: The role of psychological safety. Journal of Management and Organization, pp. 1-20.

Johanson, J., \& Mattsson, L.-G. (1988). Internationalization in Industrial Systems - A Network Approach. In N. Hood \& J.-E. Vahlne (Eds.), Strategies in Global Competition (pp. 287314). New York, NY: Croom Helm.

Johnson, J. L., \& Arunthanes, W. (1995). Ideal and actual product adaptation in US exporting firms. International Marketing Review, 12(3), 31-46. 
Jones, G. (2010). Multinational Strategies and Developing Countries in Historical Perspective. Harvard Business School Entrepreneurial Management Working Paper No. 10-076.

Karnani, A. (2007). The Mirage of Marketing to the Bottom of the Pyramid: How the Private Sector Can Help Alleviate Poverty. California Management Review, 49(4), 90-111.

Khayesi, J. N. O., \& George, G. (2011). When does the socio-cultural context matter? Communal orientation and entrepreneurs' resource accumulation efforts in Africa. Journal of Occupational and Organizational Psychology, 84(3), 471-492.

Kincheloe, J. L. (2005). On to the next level: Continuing the conceptualization of the bricolage. Qualitative Inquiry, 11(3), 323-350.

Kolk, A. (2016). The social responsibility of international business: From ethics and the environment to CSR and sustainable development. Journal of World Business, 51(1), 23-34.

Kolk, A., \& van Tulder, R. (2010). International business, corporate social responsibility and sustainable development. International Business Review, 19(2), 119-125.

Kotha, R., \& George, G. (2012). Friends, family, or fools: Entrepreneur experience and its implications for equity distribution and resource mobilization. Journal of Business Venturing, 27(5), 525-543.

Levin, D. Z., \& Cross, R. (2004). The Strength of Weak Ties You Can Trust: The Mediating Role of Trust in Effective Knowledge Transfer. Management Science, 50(11), 1477-1490.

London, T., \& Hart, S. L. (2004). Reinventing strategies for emerging markets: Beyond the transnational model. Journal of International Business Studies.

Marshall, R. S. (2011). Conceptualizing the International For-Profit Social Entrepreneur. Journal of Business Ethics, 98(2), 183-198.

Möller, K. K., \& Halinen, A. (1999). Business Relationships and Networks: Industrial Marketing Management, 28(5), 413-427.

Nijhof, A., Fisscher, O., \& Looise, J. K. (2002). Inclusive innovation: a research project on the inclusion of social responsibility. Corporate Social Responsibility and Environmental Management, 9(2), 83-90.

Palepu, K. G., \& Khanna, T. (2010). Winning in Emerging Markets: A Road Map for Strategy and Execution. Boston, MA: Harvard Business School Publishing.

Park, S. H., \& Ungson, G. R. (1997). The effect of national culture, organizational complementarity, and economic motivation on joint venture dissolution. Academy of Management Journal, 40(2), 279-307.

Patil, N. A., \& Laishram, B. (2016). Public-private partnerships from sustainability perspective a critical analysis of the Indian case. International Journal of Construction Management, 16(2), 161-174.

Perez-Aleman, P., \& Sandilands, M. (2008). Building Value at the Top and the Bottom of the Global Supply Chain: MNC-NGO Partnerships. California Management Review, 51(1), 2449. 
Pervez, T., Maritz, A., \& De Waal, A. (2013). Innovation and social entrepreneurship at the bottom of the pyramid - A conceptual framework. South African Journal of Economic and Management Sciences, 16(5), 54.

Pitelis, C. N., \& Teece, D. J. (2018). The New MNE: "Orchestration" Theory as Envelope of "Internalisation" Theory. Management International Review, forthcoming.

Planning Commission. (2013). Draft Compendium of PPP Projects in Infrastructure. New Delhi, India.

Porter, M., \& Kramer, M. (2011). Creating Shared Value. Harvard Business Review, I(Jan Feb 2011), 63-77.

Prahalad, C. K. (2004). The Fortune at the Bottom of the Pyramid: Eradicating Poverty through Profits. Upper Saddle River, NJ: Wharton School Publishing.

Prahalad, C. K. (2012). Bottom of the Pyramid as a Source of Breakthrough Innovations. Journal of Product Innovation Management, 29(1), 6-12.

Prahalad, C. K., \& Hart, S. L. (2002). The Fortune at the Bottom of the Pyramid. Strategy+Business Magazine, (26), 273.

Prahalad, C. K., \& Krishnan, M. S. (2008). The new age of innovation: Driving cocreated value through global networks (1 st editio.). New York, NY: McGraw-Hill.

Prahalad, C. K., \& Mashelkar, R. A. (2010). Innovation's Holy Grail. Harvard Business Review, $88(7-8)$.

Quarshie, A. M., Salmi, A., \& Leuschner, R. (2016). Sustainability and corporate social responsibility in supply chains: The state of research in supply chain management and business ethics journals. Journal of Purchasing and Supply Management, 22(2), 82-97.

Rajan, R. (2007). Unilever's Business in India's Subsistence Economies. Advances in International Management.

Reficco, E., \& Márquez, P. (2012). Inclusive Networks for Building BOP Markets. Business and Society, 51(3), 512-556.

Rosca, E., Arnold, M., \& Bendul, J. C. (2016). Business models for sustainable innovation - an empirical analysis of frugal products and services. Journal of Cleaner Production, 1-13.

Shafiulla, B. (2014). Tata Nano to Tata No-No. The IUP Journal of Marketing Management, XIII(1), 78-87.

Sharma, A., \& Iyer, G. R. (2012). Resource-constrained product development: Implications for green marketing and green supply chains. Industrial Marketing Management, 41(4), 599608.

Singh, R., Gupta, V., \& Mondal, A. (2012). Jugaad-From "Making Do" and "Quick Fix" to an Innovative, Sustainable and Low-Cost Survival Strategy at the Bottom of the Pyramid. International Journal of Rural Management, 8(1-2), 87-105.

Sinha, P. K., Gupta, S., \& Rawal, S. (2017). Brand adoption by BoP retailers. Qualitative Market 
Research: An International Journal, 20(2), 181-207.

Stiglitz, J. E. (2012). The Price of Inequality: How Today's Divided Society Endangers Our Future. New York, NY: W.W. Norton \& Company Inc.

Sunduramurthy, C., Zheng, C., Musteen, M., Francis, J., \& Rhyne, L. (2016). Doing more with less, systematically? Bricolage and ingenieuring in successful social ventures. Journal of World Business.

Tihanyi, L., Griffith, D. A., \& Russell, C. J. (2005). The effect of cultural distance on entry mode choice, international diversification, and MNE performance: A meta-analysis. Journal of International Business Studies, 36(3), 270-283.

United Nations. (2015). Transforming our world: the 2030 Agenda for Sustainable Development. In General Assembly Resolution 70/1, 25 September 2015 (Vol. 16301, pp. 1-40). http://unctad.org/meetings/es/SessionalDocuments/ares70d1_es.pdf

United Nations. (2016). The Sustainable Development Goals Report 2016. United Nations (Vol. 2016). United Nations.

Vachani, S., Doh, J. P., \& Teegen, H. (2009). NGOs' influence on MNEs' social development strategies in varying institutional contexts: A transaction cost perspective. International Business Review, 18(5), 446-456.

Vadakkepat, P., Garg, H. K., Loh, A. P., \& Tham, M. P. (2015). Inclusive innovation: getting more from less for more. Journal of Frugal Innovation, 1(1), 2.

Vernon, R. (1966). International Investment and International Trade in the Product Cycle. The Quarterly Journal of Economics, 80(2), 190-207.

Vinson, D. E., Scott, J. E., \& Lamont, L. M. (1977). The Role of Personal Values in Marketing and Consumer Behavior. The Journal of Marketing, 41(2), 44-50.

Weber, C., Weidner, K., Kroeger, A., \& Wallace, J. (2017). Social Value Creation in InterOrganizational Collaborations in the Not-for-Profit Sector - Give and Take from a Dyadic Perspective. Journal of Management Studies, 54(6), 929-956.

Weick, K. E. (1989). Theory Construction as Disciplined Imagination. Academy of Management Review, 14(4), 516-531.

Wernerfelt, B. (1984). A resource-based view of the firm. Strategic Management Journal, 5, 171180.

Yamin, M., \& Andersson, U. (2011). Subsidiary importance in the MNC: What role does internal embeddedness play? International Business Review, 20(2), 151-162.

Zeschky, M. B., Winterhalter, S., \& Gassmann, O. (2014). From Cost to Frugal and Reverse Innovation: Mapping the Field and Implications for Global Competitiveness. ResearchTechnology Management, 57(4), 20-27.

Zhu, F., Zou, S., \& Xu, H. (2017). Launching reverse-innovated product from emerging markets to MNC's home market: A theoretical framework for MNC's decisions. International Business Review, 26(1), 156-163. 